\title{
J
}

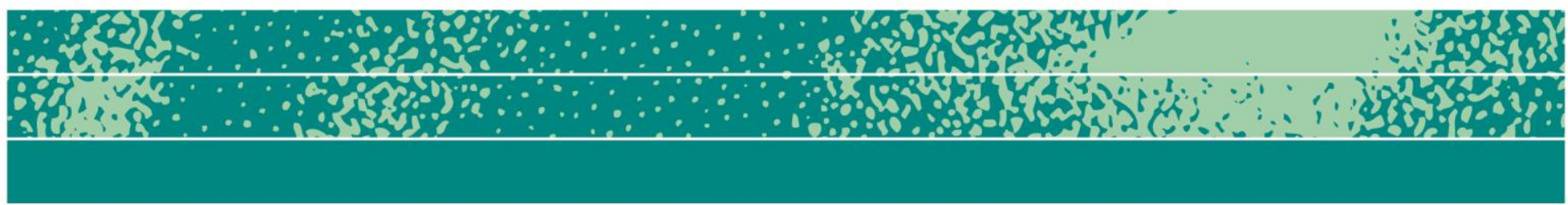

\section{"Calling it a Crisis": Modes of Creative Labour and Magic in an Elite Architect Company}

\author{
Aina Landsverk Hagen
}

\begin{abstract}
In recent years we have seen a resurfacing of magic as an analytical category in anthropological literature, with particular emphasis on modern forms of occultism and witchcraft. Magic has yet to prove itself a useful analytical tool within the anthropology of organizations, and this article aims at understanding everyday work processes through the concepts of myth and magic. The discussion is based on empirical data from an internationally acclaimed architect company based in Norway, with a particular focus on a period of downsizing in the aftermath of the global financial crisis in 2008. The architects try to uphold an egalitarian, social-democratic ideology of creativity within a capitalist system and make use of a range of magical practices in order to succeed. The article shows how narrative flexibility transforms the brutality of downsizing into a mode of creative labour, and concludes that the internal dynamic between risk taking and risk reducing is inherent in both magical practices and capitalist systems.
\end{abstract}

Page 1 of 18

JBA 4(2): 201-218 Fall 2015

(C) The Author(s) 2015 ISSN 2245-4217

www.cbs.dk/jba

\section{Keywords}

Organizations, creativity, architects, magic, downsizing, flexibility 


\section{Introduction}

"No human beings, at whatever stage of culture, completely eliminate spiritual preoccupations from their economic concerns."

Malinowski (1935:vi)

In the aftermath of the global financial crisis in 2008, companies all over the world struggled to survive. Even though Scandinavia was not hit the hardest, the crisis also had repercussions for the everyday life of employees in the social-democratic welfare states. In Norway, the office space of an elite architect company went from bustling frenzy to subdued silence when 140 employees were reduced to half the number in a little over a year. It happened in two major bulks during my fieldwork, affecting the ongoing creative processes in which the architects were involved. The Company has had a turbulent history from its genesis in 1989 when a loose group of unknown, newly educated architects won their first world famous commission.

This was not the first time the Company had to downsize. Still something was different this time around. Coinciding with the repercussions of the financial crisis in 2010 was the process of reorganizing the Company structure into several entities. This was presented to the employees in all-hands meetings as a move to secure the company brand, its legal rights and intellectual properties and systems: in short, to reduce risk in what was framed by the management as a time of "crisis." Project groups would be transferred from the mother company to other entities one at a time during the winter months. There was a slight, whispering unease among the employees at this news: what would happen to groups that lost a competition or failed to get a contract signed during that period? What would be the criteria for receiving notice of dismissal that year?

\section{"It's like paradise"}

Junior architect Katherine ${ }^{1}$ was one of those receiving notice of temporary dismissal in February 2010. When she didn't seem all that disenchanted, I asked her whether she still felt lucky to have been employed in this particular company? She replied, "Yes, it's really different than most offices I think. It's like paradise." This puzzled me. The architects seemed to be systematically overworked, in addition to being hired and fired depending on financial fluctuations, but they nonetheless expressed their love for the company. Why? To understand this paradox, I see downsizing as being a mode of creative labour generally accepted by the employees, but only if it is accompanied by a narrative flexibility that upholds the autonomous character of their everyday creative practices. I employ the notion of magic as a general aspect of such work practices,

\footnotetext{
${ }^{1}$ All names are pseudonyms.
} 
using the internationally acclaimed architect company based in Norway as an empirical location for my discussion.

The ethnographic study presented here is based on extended fieldwork in the Company's two open office landscapes-a warehouse in the inner Oslo-fjord, and a renovated office space on lower Manhattan-during the period 2008-2012. It consists of more than 50 indepth interviews in Oslo and New York, the filming of about 100 hours of group work, participation in several sessions of communal reflecting on internal work processes and methodology, and a number of action research workshops facilitated by my research team in a larger project on everyday creativity in the workplace. ${ }^{2}$ As part of my $\mathrm{PhD}$, I followed five different competition teams in the two locations, and also observed several videoconferencing meetings of a cross-branch team. During the winter of 2010, the period relevant to this article, I occupied a designated desk in the open office space of the Company, observing the collaborative work of a competition group consisting of four architects and one interior architect. I took part in a number of all-hands meetings addressing both the downsizing and structural changes of the Company, as well as everyday conversations among its employees, at lunch or at coffee breaks, and in several off-hour activities. After the fieldwork period I kept contact with the Company employees, and visited both offices on several occasions during the following years.

During the winter of 2010 Katherine became what the employees called a "50 percent-er." By not cutting full positions, the management wanted to ensure that all employees would still be coming to work every day, and hopefully get the chance to return to a full-time job if things picked up in the near future: a form of numerical flexibility (Wood 1989) made possible by the many temporally employed workers. "Yes, I am part of the club," Katherine stated when I asked for her status during the downsizing rounds. She deliberately made a sad face, before lighting up. "But actually it will not be too bad. I only get a few thousand (Norwegian kroner) ${ }^{3}$ reduction (in salary) and working 50 percent less will be good for me." I had often seen her late at night, along with many of her team partners, struggling to meet the deadline of the latest commission.

Origin myths have laid the foundation for the Company's organizational practices. One of the founders explained how "we felt that no one took us seriously. So we decided to risk everything on one big project (...). We drew it in Los Angeles. In six weeks" (Hagen 2014:69). "We had an unusual beginning," another founder stated. "You just kind of win it almost by luck." Origin myths are in general reproduced through

2 The Idea Work project was funded by the Research Council of Norway and five Norwegian partnering companies (see Carlsen et al. 2012). As contract researchers, we provided the partner firms with relevant research-based activities throughout the period 2008-2011.

3 This is equivalent to about $€ 250$, as of July 2015 . 
such intra- and extra-organizational storytelling (Czarniawska 1997, Gabriel 2000, Boje 2014), and here the myth of creative work as requiring little (although genius-like) effort, and the myth of creative flexibility and limitless hours, are induced by phrases like "we drew it in six weeks." By designing the entry within an "unreal" timeframe and in an "unreal" space, winning a major competition without any prior experience suddenly seems plausible. The serendipity, chance and hardship following the initial competition win are repeated in the media stories, but more importantly the origin myths are transmitted through the active storytelling of seniors to newcomers, to the extent that these narratives came to define the company ideology decades later.

While myths are basic ingredients in practices of magic, they also provide organizations with great opportunity for expansion (Meyer and Rowan 1977) and can be good tools for reducing risk during times of necessity. This I call narrative flexibility. The stories told and retold to new employees in the architect company emphasize exactly the connection between creativity, success, bravery and comradeship. The genesis myths tell of how the group of young architects took only weeks to complete a winning competition concept. The myths thus form the basis for the ideal creative process that, according to the employees, leads to sensory "eureka-moments" where the architectural concepts are produced collectively-the idea not coming from any single individual but from the group as a whole. This ideal process is presented to new employees as the recipe for winning competitions and acquiring commissions. These local myths are strongly linked to more general myths of creativity dominant in Western society, particularly addressing the relation between the artist, artwork, the public and the mundane.

According to one of the employees at the Oslo headquarters, "architecture is the slowest of all art forms." Architects seem to struggle with the myths surrounding artistic and architectural practices, and particularly with the assumed clear-cut opposition between imitation and innovation. The myths of creativity are as powerful as the building structures to which the architects relentlessly try to give a "liquid" form through their enchanted 3D software technology and advanced machinery. In contrast, the 2D software Autocad is a more mundane working tool mastered by all, regarded in general as old-fashioned as it only enables one to make straight lines. More advanced technology is the domain of the younger, newly educated architects who enchant their colleagues with their 3D software skills, and challenge the position of senior architects as the sought after crafters of physical models and drawings (Gell 1998). The seniors instead perform as experts on the collaborative creative process itself.

The genesis myth of this particular company, as it is presented to the external audience, contains no references to, or detailed accounts of, the actual work process of drawing the successful competition entry. The 
exception is one account of the origin myth where the creative process was explained in some detail by one of the founders:

"In an apartment downtown [Los Angeles] they slept under the tables, drew and discussed. They egged each other on. In architecture, one seldom experiences this moment of eureka (...) Strictly speaking, it's just an uncontrollable movement in the cerebral cortex-the moment you think of something you weren't able to discover before. It's an addictive feeling you want again and again." (Hagen 2014:79).

He retold one of the most solid myths of creativity: the embodied eureka moment, where the idea for the solution arrived seemingly without effort. "It is like a game where we together conjure the ideas. Something lies smoldering-and is drawn out through lengthy conversations." This moment of sensible intuition, so characteristic of artistic creation (LéviStrauss 1962/1972), was achieved only after strenuous periods of conversations and sketching. The sheer workload necessary to undertake such an intense collaborative effort was not accounted for in any of the versions of the myth circulating in the media, and so contributed to the spell-like qualities of the phrase "in six weeks," hinting at a supernatural creative outburst requiring little effort.

Architects could be described as bricoleurs (Lévi-Strauss 1962/1972:17), continuously collecting ideas, elements and inspiration from outside sources and from past design projects that never materialized. They are part of the process of constructing buildings, landscapes and interiors, and in this they are more often selling lines and "drawing for money" than making art. One of the more mundane solutions the architects in this particular firm offer to this artistic dilemma of closure and fluidity is to transform their work into everyday rituals: for example, by mounting wheels on furniture to spur mobility and flexibility; by mixing administrative and architect staff in the open office landscape; and by celebrating each employee's birthday by singing in Norwegian during lunch hour. They are also vocal in addressing issues of creativity in every project and design project groups in order to secure functional flexibility (Wood 1989). As one senior architect in the Oslo office said, "there is a tradition for not having a tradition here." In an organizational climate that disapproves of all forms of codification of work methods, the system of heightened sensory-perceptive, technologically skilled, or vocal performance acts needs to be founded on myths allowing for exactly these "moments of eureka." I identify three modes of magical practices present among these creative labourers: sensory magic, crafting magic and vocal magic.

The heroism involved in accounts of creativity hides the fact that most creative acts are acts of collaboration involving a multiplicity of actors (John-Steiner 2000; Kelley 2001; Osborne 2003; Hargadon 2003). Each mode of magical practice is connected to a particular group of 
company magicians: spiritual leaders, like the founders quoted above, who instigate internal motivation through speech acts; ritual experts, who have extensive knowledge of organizational practices; and digital gurus, who are masters of the advanced software. What I call sensory magic plays a vital role in the Company philosophy, as the "eureka moment" is highly intertwined with myths forming local ideals of everyday creative practices. In the words of the founder "it's an addictive feeling you want again and again." This feeling is one of bodily sensation and intellectual stimulation and in naming this sensory magic I define it as a practice on its own, interrelated with vocal and crafting magic (which will have to be discussed in length elsewhere).

Sensory magic is key to understanding what fuels labour in companies within the creative industry. The lines that are drawn after the process of a collective eureka moment are not the same kind of lines that are drawn "for money," even though they may look the same to the naked eye. Sensory magic has transformed and infused these lines with a combination of anarchic solidarity (Gibson and Sillander 2011) and collective will. This confirms Malinowski's (1935) argument about how spiritual preoccupations are interrelated with economic concerns-and with tangible results.

\section{Magic in anthropology}

Malinowski was part of a generation of anthropologists who revived and reconfigured the primitive notion of magic by comparing the practices of the "other" to those of the enlightened people of Western countries. The crown jewels of Britain were likened to the Kula shells of the Trobrianders, with symbolic power far outreaching their "objective" value. Advertising practices in the post-World War II era were interpreted as similar to the workings of local shamans in Asian or African communities, who use repeated words and formulas to enchant people into thinking anything is possible-whether becoming a beauty queen, falling madly in love, or procuring wealth-but also to gain control over whatever we do not want to happen.

How did the concept of magical practices come to influence anthropology? Edward B. Tyler (1871), James G. Frazer (1890) and Marcel Mauss (2002 [1950]) each in their own way discussed the symbolic meaning of magic acts, magic as a social fact, "a complex of ideas, beliefs and rites handed down from one generation to another" (Greenwood 2009:9). Building on these early thoughts on magic, Malinowski (1922/1932, 1935, 1948/1992), Raymond Firth (1939/1972) and Evans-Pritchard (1937/1976) argued that magic is also a rational way of ordering society, an essential feature of the productive process in primitive economy. When the Trobrianders artistically carve dazzling canoe prow-boards for the Kula trade, the magic patterns are integral to instilling optimism that these canoes will be safe in rough and 
dangerous seas and simultaneously work to demoralize their adversaries (Gell 1992:44). The myth of the flying canoe is thus regarded as fundamental for the work practices of Trobriand carvers. The rites and spells that accompany the acts of carving also contribute to a team spirit among the voyagers (Malinowski 1935:116).

In focusing on the functional aspects of magic, anthropologists such as Malinowski outlined its systemic character: how magic acts through rites and formulas aimed at the emotional element of everyday production tasks (Malinowski 1935:60). With his confidence theory of magic, Malinowski claimed that magic has "the function of giving confidence to the worker, of acting as a supplementary sanction for the performance of the task" (1935:184). Magic does not replace technique and knowledge, but instead contributes towards economic efficiency and the integration of effective teams, becoming "also an empirical force" (Malinowski 1935:240). In this way magic has both a psychological and a sociological effect. For his part, Evans-Pritchard (1937/1976) discarded the idea of magic as a fixed total system of knowledge, arguing that it was contextually relative, dynamic, and adaptive to situations. Lévy-Bruhl (1928), on the other hand, building on Mauss (1950/2002), emphasized the cognitive and sensory aspects of magic, seeing magic as "a process of mind that goes beyond either sociological or psychological reduction" (Greenwood 2009:10). To Lévy-Bruhl the metamorphosis of bodily awareness was a part of the sensory and psychic connection with both material and non-material reality, an embodied experience referred to as "mystical mentality."

In the past decades anthropologists have used these theoretical contributions on magic in primitive societies to enlighten their interpretation of similar practices in modern culture. Alfred Gell (1992, 1998) makes extensive use of Malinowski's work on the Trobriands in his discussion on the production and reception of modern art. Although not explicitly mentioned, Lévy-Bruhl's "mystical mentality" resonates with the concept of the "distributed mind" portrayed by Gell (1998), where "the creative products of a person or people become their 'distributed mind' which turns their agency into their effects, as influences upon the minds of others" (Miller 2005:13). With new volumes on magic and modernity (Meyer and Pels 2003, Moore and Sanders 2001), witchcraft (Bond and Ciekawy 2001, Kapferer 2002, Stein and Stein 2005) and magic and fashion (Moeran 2015), contemporary anthropology sees a resurfacing of magic as an analytical category and a fruitful venue for research (Masquelier 2004). However, magic has yet to prove itself as a useful analytical tool within the anthropology of organizations and in the following discussion I will attempt to bring magic and organizations together.

Architecture has a long history of being viewed as a form of art (Rannells 1949)-an idea that brings with it certain some moral 
implications. As Alfred Gell (1992:59) has written, "if artists are paid at all (...) it is a tribute to their moral ascendancy over the lay public," and he goes on to argue that artists' magical production is the reverse of productive technology. When divine inspiration and ancestral spirits fill the artist, she is not working "for us," and thus, in the contexts of artistic production, the trivial world of contract formulations and cost assessment seems to be disenchanting, or even morally wrong. Art is thus "a black box," of which we, the audience, are in awe when we see the result. Like most professions within the creative and knowledge industries, architects are also dependent on their ideas being acknowledged as exciting and inspiring by others. But what happens if this strategy of enchanting the audience does not succeed in securing enough revenue?

\section{Walking the lay off line}

\section{Thursday, February 17, 2010, the Oslo office}

The snow is no longer falling. The sky is dense grey-only hints of blue streaks break the surface.

Inside. Quiet. Still air. A petite, smartly dressed, brownhaired woman is walking the aisles of architects pretending to be at work. The atmosphere is thick with the absence of the sounds of normality. The woman bears a compassionate, but strict expression of determination. Nobody wants to pay her attention, yet everyone's senses are fully tuned in to her movements. Is she slowing down? Does her body aim towards this column? Are her eyes fixed on someone in that row?

Her concentrated movements yell out the answer to what is wondered in silence: Is it my turn? Your turn? His or her turn to go?

The task she has been assigned affects everyone's activity these dreaded days. People avoid each other to avoid her. Their looks are empty, revealing nothing, asking nothing. Their voices anxiously mellow. She is bringing the word on who's in and who's out. The one thing you don't want in your hand today is a sheet of white paper bearing the black inked notification of your temporary dismissal.

The Company champions a kind of creativity that its managers and employees identify as "egalitarian and social-democratic." Both work hard to avoid traditional practices of artistic mentors telling others what to define as "creative" and how to draw. New employees are expected to speak out, to contribute with ideas on the same level as any senior, and to take full responsibility for the work that has to be done. The managers 
deny any hint of "archistar" status (Lo Rocco \& Micheli 2003 in La Cecla 2012), as "everyone has an equal voice" in the Company lingo. The organization promotes a highly collaborative approach to creative practices and a philosophy of "self-structuring chaos." But these are all practices that come with a cost, something that became poignant in the aftermath of the global financial crisis of 2008.

The question of who would be laid off created a lot of unease and muffled discussions during the winter months of 2010. The only vocal outburst of anger I witnessed came from a senior architect. She voiced her frustration loudly one day, sitting at her desk in the open office landscape: "It is inhumane! People are walking around waiting to know if it concerns them." No one answered her exclamation and muffled voices once again took over the office soundscape, in Ingold's (2011) term. The architects explained how the sharing of space-for example, by means of voices and the constant movement of bodies-automatically effectuated the sharing of ideas. They linked the bustling, loud office atmosphere directly to their ability to work creatively and collaboratively. It was the typical creative organization (Witz et al. 2003, Schwarz 2003), appearing to any approving observer as something of an ideal community of workers collaborating amiably with a common mission of making a difference in the world. During the first round of lay-offs in 2009, a young architect remarked, nodding towards the desk area of the office landscape: "It's like a funeral here. People are losing their jobs tomorrow, but still they work like they're obsessed with meeting a deadline." The initial strategy of a temporary reduction in work hours had led to many employees working extra, as they would just stop registering the hours they worked instead of going home midday, not eager to leave their colleagues with a double workload. So they stayed at their desks, drawing steadily on the computers-without registering the labour and consequently not getting paid for it. Silence had been a rare phenomenon in this particular soundscape of elite architects, but now it was reigning in the rebuilt warehouse building.

At one point I asked one of the many young German architects in the office: why was no one kicking and screaming or, at least, showing some emotion during these layoff days? Why was it so nerve-rackingly silent in an office landscape that was usually so pulsating? David did have an answer ready (and it was one that at the time surprised me): "I think it is because everyone likes the Company so much, despite what's happening." He continued, "My friends in Europe, they lost their jobs and just hate their company now. Nobody [here] talks about it [the downsizing]; only those who are close friends." He considered his last statement and added, "And often not even then. People don't even know who is on temporary contracts, they don't want to ask." This avoidance can be seen to reflect the Scandinavian idea of equality as meaning "equal worth" [likeverd in Norwegian] (Gullestad 1989), where every person's voice is equally important, regardless of their employment status. The 
local cultural phenomenon of refraining from posing differences as general themes in social interaction (Vike 2001) adds generalizability to David's claim that they refrained from interrogating their colleagues' employee status.

Another line of explanation is connected to the magic of the origin myths. In a research-facilitated workshop session in April 2009, landscape architect Magnus elaborated on the uniqueness of the Company, contrasting it with much more "random" tasks or marketoriented companies.

"There is a greater will to discuss issues here-even now, when times are tougher, and discussions must be held with people that unfortunately have to leave. The discussion between us employees and the management group on whether we would decrease our salary or let people go. What is always the argument is that we will certainly not lower the quality of our architecture. We are not selling ourselves out or taking on assignments we don't believe in. This implies that what I call 'the mission of the company' will not be compromised."

He went on to argue that this "mission" was triggered by an integral aspect of architectural practice.

"In a way, it all comes down to a form on a personal level, from the big mission, that if this mission doesn't feel right to me, then I won't be able to contribute. I feel that the Company is really good at this-that one feels this mission. It feels logical: "This is how it is supposed to work.'”

This employee's reflections implied that downsizing as a strategy in times of hardship was viewed as a legitimate practice by the staff, and that it was preferable to "selling out." The discussion that he referred to, between employees and the management group, about whether they should decrease salaries or let people go, took place during several allhands meetings in the winter months of 2009 and 2010. The financial situation was strained and the management introduced several options for the staff to discuss in the obligatory meetings that took place in the lunch area at irregular intervals. These gatherings had the important function of disseminating information about the financial and organizational situation directly to the employees, but also of enabling them to voice their opinions and concerns to each other and the managers.

The all-hands meetings are a requirement of the Norwegian Work Environment Act, but they were also an organizational ritual that curbed the feeling of risk, just as acts of crafting are accompanied by rites and spells that lead to enhanced team spirit (Malinowski 1935:116). In the allhands meetings conducted during the winter of 2010, the messages from 
the management were increasingly sombre. Just before Christmas a reduction in bonuses and salaries was discussed; in the following February, it eventually became necessary to hand out temporary dismissals. Despite the sombre messages, these all-hands meetings underlined the compassionate nature of the Company (and the welfare state), the message being that no one was alone in these times of hardship, that compensation for loss of pay would be given by the state, and that the management was working creatively to figure out ways to get out of the situation without permanent dismissals-a practice called "flexicurity" (Wilthagen and Tros 2004).

The higher the risk, the greater the need for rituals like anniversaries and all-hands meetings, and it is in this territory of dealing with danger that magic in the Malinowskian (1932) sense belongs. The financial state of architectural offices in general depends first and foremost on signing contracts after winning competitions or securing commissions, contracts that not always reflect the amount of work that will be put into the design process. ${ }^{4}$ In Europe, open competition is the most usual form, where anyone, even inexperienced architects, may enter a proposal-this is how the Company won its first contract in 1989: in the words of one of the founders, "you just kind of win it almost by luck." Juries decide on anonymous entries of more or less finished concept models. This contributes to the magical character of genesis myths, since success can come from "nowhere," as it did in this case. This also affects the value of creativity within the industry, in that the competition phase itself (four-five months) is generally seen as the most creative phase of any architectural process. This is when collaborative creativity can arise from "nothing" in a most magical way, just as related in the Company's the genesis myth.

After winning a competition, the next step is approval of cost estimates. Getting the client or contractor to sign the agreement is therefore of crucial value to a company's finances, and thus has consequences for the fluctuating number of employees. To get the contract to cover most of the actual costs is an issue of substantial concern, as entering competitions is an expense in itself for the architectural firms involved. Even if the company is invited and receives a fee, the latter is seldom enough to cover the hours of work invested in such a process. In this economy of fame the architects are highly dependent on winning esteemed prizes and media coverage through prestigious projects that can bring "cultural capital" (Bourdieu 1984/2010:124) to the company and only in some cases large commissions become profitable. To compensate for this risk, a lot of companies instead "draw for money" by designing traditional office buildings and hotels. The dependence on competition success contributes

\footnotetext{
4 The manner of competing diverges in the European and American system of architecture commissions. This is discussed in more detail in Hagen (2014).
} 
to making the logic of "numerical flexibility" (Wood 1989) seem legitimate, as a permanent full-time workforce is complemented after winning a competition by employees hired on short-term contracts. If a contract fails or is stalled, these temporary employees have to go. Kathrine, who views the Company as "paradise," regardless of being downsized herself, seemed to accept this view.

\section{Downsizing, magic and creativity}

According to Mauss (2002/1950), magic is by definition believed. It is also felt as a sensory experience (Lévy-Bruhl 1928). It is handed down through generations by means of myth telling and thus becomes a social fact, an emotional element of everyday work. What the architect above described as "the mission" is something the Company had never written down, documented or codified. It can rather be described as a philosophy of work that was being handed down by "ritual experts"-informal leaders who are often (but not always) senior in position, and who both guide and sanction new employees in their social and work-related conduct by means of their narratives. Maja, one of these ritual experts, shared her personal experience of such a collective "eureka moment" with her younger colleagues in the following manner:

"It was like this big vision when we got the idea of this tilted plane. Everybody was so excited, it was like a spiritual experience and everybody had this like-wow, what a fantastic idea! It's like everybody went home and dreamt about this, sloping planes, and then we were fighting like crazy for five weeks, because we could never agree exactly how to do it. But I think it really didn't matter, because we all believed in the main idea, and we could do it many ways. In the end it was the logic of the idea itself that was the driving force and the main guide."

The embodied experience of "mystical mentality" (Lévy-Bruhl 1928) is reflected in the ideal practices that the architects repeatedly discuss during project meetings and reflection seminars as the key to their success. These in-house stories of creative collaborative labour celebrate the sensory connections to collective ideas as the preferred method of working. At the same time, sensory magic is seen as an uncontrollable force only possible to release through ongoing sessions of collective vocal magic, never by prescription or systematization.

At this point, a Swedish architect, Magnus, interrupted:

"You also say that the experience was a physical sensation in the body."

Maja: "Yeah.”

Magnus added: "You can almost feel your spine burning." 
Luke, a young American, broke into the conversation.

"This is important. We know it's important, because the results are fantastic. They are there forever."

When the younger architects ask Maja whether such eureka moments can be planned for or facilitated, she refused to answer. Instead she insisted on how "you know it when it happens." Company myths like this, then, function as the only "recipe" for these architects' everyday work practices. They disclose the procedures and essential elements of an "ideal" execution of entries to architectural competitions. The storytelling practices in the Company are extensive and a part of celebratory rituals, reflection sessions, and everyday work life. "For societies without writing and without archiving the aim of mythology is to ensure that (...) the future will remain fateful to the present and the past," Lévi-Strauss (1978/1995) writes. The Trobriand Myth of the Flying Canoe (Malinowski 1922/1932) discloses how the "full knowledge of magic" enabled a canoe to fly through the air from an inland village, arriving safely on all the islands in the Kula exchange chain. The narrative functions as an introduction to the extensive use of magical rites, formulas and spells in the natives' main labour activities: yam cultivation and canoe building. In addition, the elements presented throughout the tale give a full rendition of the techniques and procedures for carving the canoes that are so important to the native's economy of fame, the Kula trade (Malinowski 1922/1932).

Risk-taking is what many of the architects identify as a characteristic of their organization. In response to a presentation of the new company structure at an all-hands meeting, senior architect Håkon exclaimed: "Minimize risk? The Company takes risks. (...) We have to do both at the same time: make brilliant architecture and earn money." The difference that makes a difference (Bateson, 1972/2000) in the history of the Company is that, according to Håkon, "this time we're calling it a crisis."

\section{Crisis in paradise}

Technique is supposed to be dull and mechanical, opposed to true creativity and such authentic values that art represents. This is a distorted view, according to Gell (1992:56), who argues that the technical activity is also the source of the efficacy of our social relations. In periods of financial stability, the few young "digital gurus," who had mastered 3D software like Rhino and Grasshopper, gained respect and status for their enchanting abilities. During the downsizing periods I noticed how the monotonous, and thus silent, work suddenly surfaced with meaning and purpose, in contrast to the celebration of "creative buzz" and the enchanted 3D models and renderings. The vocal magic of the spiritual leaders was subdued during this period. Rather, it was the traditional, 
mundane crafting magic that kept them afloat through the treacherous waters of the financial crisis. And, when I dared to ask, the architects fiercely refused to describe the labour of these months as less creative. The 2D software AutoCAD, a democratic tool enabling everybody to perform, became a sacred object (Durkheim 1912/1974:44) during the downsizing, securing momentary inclusion and belonging. Thus, when the employees no longer controlled who was included in or excluded from creative work, they compensated by performing egalitarian ideals through the tools they all knew how to use.

When the architects artistically "carve" dazzling 3D designs and print miniature models that enchant their audience, they also work to demoralize their adversaries (Gell 1992:44). The optimism that these design concepts would somehow provide safety in rough and dangerous seas was dependent upon managers doing a good job handling the economic side of the business. The employees' strong emphasis on an egalitarian, social-democratic ideology seemed never to subside during, or after, this period of downsizing, despite the sudden introduction of what the architects deemed to be "inhumane" practices of temporary and permanent dismissal. When I repeated my question to a Norwegian senior architect with more than 15 years' experience in the Company-why was no one rebelling during the lay-off periods?-she said quietly: "It is horrible to say, but we have nowhere to go. We are like an abused child. This is what we believe in." The social fact of the magic inherent in the creative processes seemed to make them captive to their own talents and aspirations. In becoming true believers in these particular practices of creativity, it was difficult to transform yourself into becoming an architect "drawing for money," or accepting orders and strict regulations.

The repercussions of the financial crisis and the capitalist system highlight how the architects are inextricably interwoven as employees, consumers, and salesmen of lines. This might explain why they like the Company this much, why they claim that they cannot find a (truly creative) job elsewhere-despite the brutal acts of exclusion in times of hardship. Regardless of the management's efforts to avoid layoffs, the Oslo branch lost half its staff within little over a year. With hindsight, it became clear that few of the digital gurus and the ritual experts were given permanent notes of dismissal. The magicians stayed in the realm. Despite the Company's past history of taking chances and jumping on opportunities often way beyond their control, and thus winning prestigious competitions, reducing risk became the mantra of the third decade of the Company's existence.

\section{Conclusion}

The principles of a magical system are inherent in every important human activity involving danger, uncertainty and chance (Firth 1939/1972; 
Malinowski 1935, Mauss 1950/2002). A diverse set of moralities and values affect both employees and management's decisions, reactions and sentiments during the unstable times that followed the global financial crisis in 2008. To deal with the dilemmas and ambivalences surfacing from the paradoxical state of being "equally genius" in a capitalist economy, these architects made use of a range of "magical practices" in their everyday work-practices inherent in modern organizations to set things or people in motion. Faced with the harsh reality of market exploitation, they were not the only profession in the knowledge domain to struggle in actualizing their ideas into "any existence whatever" (Colebrook 2008:80). A narrative flexibility enabled collaborative creativity through the ideals promulgated to new employees, but it also transformed the brutality of downsizing into a mode of creative labour.

The origin stories of success in the Company have never been documented in writing, but are retold and reshaped depending on the situation. In this way, stories are used as a way of being able to downsize (and upsize) with compassion and empathy through the narrative flexibility of the origin myths recaptured at the beginning of this article. This form of flexibility hides the brutality of risk-taking and risk-reducing practices. The vocal magic of the directors and the original staff is essential to install confidence in the employees, and the buildings that they design are tangible proof that success is within reach. The implications of defining architecture as an art form within a strictly capitalist system necessitates the building of "impossible" organizational structures, where revenues do not readily appear in the shape of money, but rather as a continuous stream of acknowledgements spurred by their risk-taking design practices. Both magical practices and capitalist systems thus feed from the internal dynamic between risk taking and risk reducing.

Magic can be seen as a naturalization of human actions (LéviStrauss 1962/1972:221). The senior architect quoted earlier refused to accept the artistic myth of the starving artist unable to earn money, because in his view there had never been a contradiction between making money and "brilliant architecture." Nonetheless, now they were going to reduce risk by evoking the "magic counting dragon" (Clarke and Hamilton 2013) of capitalist systems, created to achieve mastery and control in institutional settings. Calling it a crisis might be just another act of magic.

\section{References}

Boje, D.M. 2014. Storytelling Organizational Practices: Managing in the Quantum Age. London: Routledge.

Bond, G. C. and Ciekawy, D.M. Eds. 2001. Witchcraft Dialogues:

Anthropological and Philosophical Exchanges. Athens, OH: Ohio University 
Press.

Bourdieu, P. 2010 [1984]. Distinction: A Social Critique of the Judgement of Taste. London and New York: Routledge.

Carlsen, A., S. Clegg and R. Gjersvik. 2012. Idea Work. Oslo: Cappelen Damm.

Clarke, P. K. and W. T. Hamilton 2013. "The value of anthropology: noticing and challenging the magic counting dragon." Anthropology News. 54(1-2):31.

Colebrook, C. 2008. "On not becoming man: the materialist politics of unactualized potential." In Material Feminisms. Alaimo, Stacy and Susan Hekman (eds.), pp: 52-84. Bloomington and Indianapolis: Indiana University Press.

Czarniawska, B. 1997. Narrating the Organization: Dramas of Institutional Identity. Chicago: University of Chicago Press.

Deleuze, G. and Guattari, F. 1987. A Thousand Plateaus: Capitalism and Schizophrenia. Minneapolis: University of Minnesota Press.

Durkheim, E. 1974 [1912]. The Elementary Forms of the Religious Life, London: George Allen \& Unwin.

Evans-Pritchard, E.E. 1976 [1937]. Witchcraft, Oracles and Magic among the Azande. London: Clarendon.

Firth, R. 1972 [1939]. Primitive Polynesian Economy. London: Routledge and Sons, Ltd.

Frazer, J. G. 1890. The Golden Bough: A Study in Magic and Religion.

Accessed on Project Gutenberg, www.gutenberg.org.

Gabriel, Y. 2000. Storytelling in Organizations: Facts, Fictions, and Fantasies. Oxford: Oxford University Press.

Gell, A. 1992. "The technology of enchantment and the enchantment of technology." In Anthropology, Art, and Aesthetics. Coote, J. and A. Shelton (eds.), pp: 40-66. Oxford: Clarendon Press.

Gell, A. 1998. Art and Agency: An Anthropological Theory. Oxford: Oxford University Press.

Gibson, T. and K. Sillander (eds). 2011. Anarchic Solidarity: Autonomy, Equality, and Fellowship in Southeast Asia. Monograph 60. New Haven, Connecticut: Yale University Southeast Asia Studies.

Greenwood, S. 2009. The Anthropology of Magic. Oxford: Berg.

Gullestad M. 1989. Kultur og hverdagsliv [Culture and everyday life]. Oslo: Universitetsforlaget.

Hagen, A. L. 2014. Fear and Magic in Architects'Utopia: The Power of Creativity among the Snøhettas of Oslo and New York. Dissertation thesis. 
Faculty of Social Sciences, University of Oslo.

Hargadon, A. H. 2003. How Breakthroughs Happen: The Surprising Truth About How Companies Innovate. Boston, Mass: Harvard Business School Press.

Ingold, T. 2011. Being Alive: Essays on Movement, Knowledge and Description, London: Routledge.

John-Steiner, V. 2000. Creative Collaboration. New York: Oxford Press.

Kapferer, B. (ed.) 2002. Beyond Rationalism: Rethinking Magic, Witchcraft and Sorcery. New York: Berghahn.

Kelley, T. 2001. The Art of Innovation. San Francisco: Doubleday.

La Cecla, F. 2012. Against Architecture. Oakland, CA: The Green Arcade.

Lévi-Strauss, C. 1972 [1962]. The Savage Mind. London, UK: Weidenfeld and Nicholson.

Lévy-Bruhl, L. 1928. The "Soul" of the Primitive. London: George Allen \& Unwin. Ltd.

Lo Rocco, G. and Micheli, S. 2003. Lo spettacolo dell'architectura. Profilo dell'archistar. Milan: Bruno Mondadori.

Malinowski, B. 1932 [1922] Argonauts of the Western Pacific. London: George Routledge \& Sons.

Malinowski, B. 1935. Coral Gardens and Their Magic. A Study of the Methods of Tilling the

Soil and of Agricultural Rites in the Trobriand Islands. London: Allen \& Unwin.

Malinowski, B. 1992 [1948]. Magic, science and religion and other essays. Prospect Heights, Illinois: Waveland Press.

Masquelier, A. 2004. "The return of magic." Social Anthropology 12(1): 95102.

Mathiesen, T. 1997. "The viewer society: Michel Foucault's 'Panopticon' revisited." Theoretical Criminology 1(2): 215-234.

Mauss, M. 2002 [1950]. The Gift: The Form and Reason for Exchange in Archaic Societies. London: Routledge Classics.

Meyer, B. and Pels, P. (eds.) 2003. Magic and Modernity: Interfaces of Revelation and Concealment. Stanford: Stanford University Press.

Meyer, J.W. and Rowan, B. 1977. "Institutionalized organizations: formal structure as myth and ceremony." American Journal of Sociology 83(2): 340-363.

Miller, D. (ed.) 2005. Materiality. Durham: Duke University Press.

Moeran, B. 2015. Magic of Fashion: Ritual, Commodity, Glamour. Walnut 
Creek, CA: Left Coast Press.

Moore, H. and Sanders, T. 2001. Magical Interpretations, Material Realities. Modernity, Witchcraft and the Occult in Postcolonial Africa. London: Routledge.

Osborne, T. 2003. "Against creativity: a philistine rant." Economy and Society 32(4): 507-525.

Rannells, E. W. 1949. "The study of architecture as art." College Art Journal 8(3): 204-208.

Schwarz, H. 2003. "Mobile workplacing: office design, space and technology." In Technologies at Work: People, Screens and Social Virtuality. Garsten, C. and H. Wulff (eds.), pp. 91-117. New York: Berg.

Stein, R.L. and Stein, P.L. 2005. The Anthropology of Religion, Magic and Witchcraft. Boston, MA: Pearson/Allyn and Bacon.

Sharp, L. R. 1943. "Notes on Northeast Australian totemism." Studies in the Anthropology of Oceania and Asia. Papers in the Peabody Museum. Vol. 20: 66-71. Cambridge, Mass: Harvard University.

Strathern, M. 2004 [1991]. Partial Connections. Walnut Creek, CA: Rowman Altamira.

Tyler, E. B. 1871. Primitive Culture. Researches into the Development of Mythology, Philosophy, Religion, Art, and Custom. London: J. Murray.

Vike, H. 2001. "Norsk kultur: Realitet og myte" [Norwegian Culture: Myth and Reality]. In Flerkulturell forståelse [Multicultural Understanding]. T. Hylland Eriksen (ed.), pp. 134-153. Oslo: Universitetsforlaget.

Wilthagen, T. and F. Tros. 2004. "The concept of 'flexicurity': a new approach to regulating employment and labour markets." In «Flexicurity: Conceptual Issues and Political Implementation in Europe.» European Review of Labour and Research 10(2):166-186.

Witz, A., Warhurst, C. and Nickson, D. 2003. "The Labour of Aesthetics and the aesthetics of organization." Organization 10(1): 33-54.

Wood, S.J. (ed.) 1989. The Transformation of Work? Skill, Flexibility and the Labour Process. Boston, MA: Unwin Hyman.

Aina Landsverk Hagen holds a PhD in social anthropology from the University of Oslo, Norway. She is currently employed as a senior researcher at the Work Research Institute at Oslo and Akershus University College of Applied Sciences, Norway. Her research interests include gender, social and power relations, freedom of speech, anthropology of magic and creativity within organizations. She may be reached at aina.hagen@afi.hioa.no 